\title{
O LADO SOMBRIO DA ESTRADA Vitimização, Gestão Coercitiva e Percepção de Medo nos Roubos a Ônibus Interurbanos*
}

\section{Eduardo Paes-Machado}

Universidade Federal da Bahia (UFBA), Salvador - BA, Brasil. E-mail: epaesm@gmail.com

\section{Silvia Viodres-Inoue}

Universidade Católica de Santos (Unisantos), Santos - SP, Brasil. E-mail: silviaviodres@yahoo.com.br

DOI: http//dx.doi.org/10.17666/308909-30/2015

\section{Introdução}

Conquanto o crime de roubo tenha declinado de modo significativo, a exemplo de outros delitos violentos, nos Estados Unidos (Blumstein e Wallman, 2006; Zimring, 2007), ele continua em ascensão em outras regiōes do mundo. Este é o caso de países da África (Roitman, 2004) e América Latina, onde, entre várias formas inéditas de roubo, estão os ataques a ônibus de passageiros que influenciam nas condições de mobilidade, nas operaçôes das empresas de transporte e no bem-estar e sensação de segurança de tripulantes e usuários. ${ }^{1}$

* Agradecemos aos auxiliares de pesquisa Josair Telles, Patrique Almeida e Taiala Aguilán, aos pareceristas e a equipe de redação da $R B C S$. Também somos gratos a Carlos Linhares, da Unifacs, Salvador, pelos valiosos comentários e sugestões.

Artigo recebido em 11/03/2014

Aprovado em 19/03/2015
Entretanto, apesar destes impactos e das modalidades específicas que assumem, tais ataques predatórios não mereceram atenção dos estudiosos.

Ora, o balanço da vasta literatura acerca desse delito predatório mostra três perspectivas de estudo (McCluskey, 2013): as tipologias de roubos (a exemplo de Normandeau, 1968), as características dos indivíduos que cometem este delito (Gill, 2000; Wright e Decker, 1997, entre outros) e a transação entre vítimas e perpetradores em termos de força, resistência e lesão (a exemplo de Luckenbill, 1981; Tark e Kleck, 2004). Nesta terceira perspectiva destacam-se, por sua vez, as contribuições teóricas derivadas do interacionismo simbólico (Luckenbill, 1981; Best e Luckenbill, 1982), da escolha racional (Cornish e Clark, 1985; Jacobs, 2012, 2013; Copes et al., 2012) e das atividades rotineiras (Cohen e Felson, 1979; Gill, 2000, 2001). Tendo em vista a abordagem interacionista do roubo como uma transação que requer a participação mútua - de 
perpetradores e vítimas - para validar seu enquadramento (frame) coercitivo (Luckenbill, 1981), os estudiosos da escolha racional e das atividades rotineiras têm enfatizado os investimentos, as tomadas de decisão e as modalidades de condução dessa ação para impor dano ou forçar a aceitação (compliance) (Tedeschi e Felson, 1994). Ainda que os autores interacionistas tenham chamado atenção para as habilidades necessárias para a viabilização dessa troca social predatória - a exemplo da comunicação efetiva, do caráter convincente do enquadramento e da transmissão bem-sucedida de ameaças de punição conforme a reação dos alvos (Luckenbill, 1981) -, a segunda e a terceira abordagens foram adiante ao propor as noções convergentes de manipulação do medo (Jacobs, 2012, 2013), de gestão de cenas e circunstâncias (Copes et al., 2012) e de diferenciais de habilidade (Gill, 2000, 2001) para conduzir o processo coercitivo de roubo.

A manipulação do medo visa fomentar essa emoção ou apelar para a sensibilidade para promover a escolha racional das vítimas (Jacobs, 2012, 2013), levando-as a avaliar seus pertences como menos valiosos do que suas vidas ou sua integridade física e desistirem de qualquer resistência (Luckenbill, 1981; Wright e Decker, 1997; Jacobs, 2012, 2013; Lindegaard et al., 2015). Trata-se de influenciar na certeza e rapidez da aceitação, tornando mais eficiente a realização da ação mediante ameaças palpáveis como a transmissão da ilusão da morte iminente (Wright e Decker, 1997). Em outros termos, como a manutenção da orientação mútua entre assaltantes e vítimas não pode se basear apenas na coerção, os primeiros devem gerenciar impressões para afetar a definição da situação e obter o que desejam. Nesse sentido, há uma convergência entre preocupações expressivas e instrumentais nos roubos que emergem da produção do medo. Em outros termos, como a manutenção da orientação mútua entre assaltantes e vítimas não pode se basear apenas na coerção, os primeiros devem gerenciar impressões para afetar a definição da situação e obter o que desejam. A manipulação do medo opera com um gradiente crescente e decrescente de violência psicológica que limita o emprego, no contexto norte-americano, da violência física (Jacobs, 2012, 2013).
A gestão da cena e das circunstâncias depende da aprendizagem e da atualização constante de scripts ou esquemas estratégicos para conservar vantagem, prevenir ou reduzir a resistência das vítimas em cada estágio do delito (Copes et al., 2012). Isso significa dizer que, dado o caráter ambíguo e arriscado desse encontro predatório para os atores involucrados, os infratores desenvolvem conhecimentos e táticas específicos para reduzir a incerteza, manter o controle inquestionável da cena (Idem) e garantir o sucesso de suas investidas. Por outro lado, na linha teórica das atividades rotineiras (Cohen e Felson, 1979) e revisitando a distinção entre assaltantes profissionais e amadores, Gill (2000, 2001) enfatizou a distribuição desigual de habilidades técnicas e gestoras entre ambas as categorias ou tipos ideais. Tal variação resulta de diferenças quanto ao repertório de experiências, à motivação para manter o controle da situação, ao preparo para assaltar e à disposição para ameaçar e usar, de modo racional e funcional, a força. Assim, as duas categorias de assaltantes possuem atitudes contrastantes com respeito ao grau de aceitação da força física (2001), que estão refletidas, deve-se acrescentar, em seus estilos menos ou mais violentos de gestão de vítimas (Letkmann, 1973).

Em contraste com esse foco nos autores dos crimes, no presente artigo discutimos as reações e as respostas das vítimas aos roubos a ônibus interurbanos. Nesse sentido, indagamos sobre as características e os efeitos do uso da violência psicológica e física, incluindo as performances sobre a percepção de medo, a aceitação e a resistência de tripulantes e passageiros. Afirmamos que o emprego desses tipos de violência é influenciado pelas características dos veículos, pela multiplicidade de vítimas e pela interação prolongada entre estas e os assaltantes. Em termos mais específicos, mostramos que o tipo e o nível de vitimização dependem do estilo de gestão dos assaltantes, dos papéis diferenciados e respostas das vítimas nas diversas etapas do roubo. Além desta introdução, de um breve histórico dos roubos, da descrição do trabalho de campo e de uma caracterização também sucinta dos autores desse tipo de delito, este artigo tem mais uma seção em que são examinadas as fases da vitimização, seguida pelas reflexōes finais. 


\section{Breve evoluçáo dos roubos a ônibus em rodovias}

Os roubos a ônibus interurbanos têm uma história de quase cinco décadas e vêm se disseminando, ainda que de modo desigual, em muitos estados do Brasil. As evidências indicam que eles surgiram na região Sudeste, a mais desenvolvida do país. Além de os roubos noticiados concentrarem-se, até o início da década de 1980, no Rio de Janeiro e São Paulo, os indícios sugerem que eles começaram no transporte urbano e depois se estenderam ao transporte interurbano de estados e municípios. Na malha rodoviária da grande São Paulo, por exemplo, estes roubos eram praticados por duplas ou trios de assaltantes já embarcados ou que se aproveitavam das paradas para ingressar nos veículos e consumá-los. ${ }^{2}$

Comparando as duas metrópoles, em São Paulo parecia haver maior variação nas modalidades, incluindo o desvio do ônibus do seu itinerário; em contrapartida, no Rio de Janeiro, os agressores agiam em maior número e raramente desviavam os veículos do seu itinerário para consumar assaltos que, muitas vezes, acabavam em tiroteios e mortes. ${ }^{3}$ Os assaltos cometidos por supostos passageiros coexistiam com os iniciados por homens posicionados na via, sendo os primeiros os mais praticados em rodovias de regióes metropolitanas e os últimos em estradas/rodovias isoladas, onde era frequente a obstrução da via pelos assaltantes. ${ }^{4} \mathrm{Na}$ década seguinte, a situação não mudou em ambos os estados.

Rapidamente, os roubos a ônibus interurbanos se multiplicaram e diversificaram. Este foi o caso das linhas para Foz de Iguaçu, que levam comerciantes para compras em Ciudad del Este, Paraguai, paraíso do contrabando e dos sacoleiros. A partir da primeira metade dos anos de 1980, esses ônibus tornaram-se alvos de assaltantes que, também embarcados como passageiros, forçavam os motoristas a desviar os veículos até locais onde seus comparsas os aguardavam com carros de apoio para o carregamento dos produtos do roubo e a fuga (Folha de $S$. Paulo, 13/2/1984). ${ }^{5}$

Desde os primeiros relatos, constata-se uma evolução das táticas dos assaltantes de estradas. $\mathrm{O}$ desenvolvimento da abordagem direta foi acompa- nhado pelo emprego de armamento pesado e a tomada de alvos múltiplos (mais de um ônibus) para otimizar as ações. Na segunda metade dos anos de 1980, assaltantes em um carro, no Rio Grande do Sul, dispararam tiros de escopeta contra um ônibus para obrigá-lo a parar (Folha de S. Paulo, 7/1/1987). Igualmente, em meados desse período e nas duas décadas seguintes o noticiário passou a chamar atenção para o crescente emprego da violência (Misse, 2008) e os desfechos desastrosos daí resultantes para infratores, passageiros e policiais - ferimento e morte por tiro e acidente de trânsito provocado por bloqueio feito pelos infratores. Tal espiral de violência pode ter sido alimentada por ações drásticas das empresas e da polícia contra os roubos (Folha de S. Paulo, 23/11/2002), a exemplo da eliminação de infratores por policiais infiltrados entre os passageiros ${ }^{6}$ (Paes-Machado e Levenstein, 2004).

$\mathrm{Na}$ atualidade, este delito continua sendo um risco para os passageiros de, ao menos, 22 estados da federação (Polícia Rodoviária Federal, 2010). Por exemplo, em uma pesquisa nacional de vitimização com 3.248 passageiros de ônibus interurbanos, $5,3 \%$ declararam ter sido roubados no serviço intermunicipal, $5,8 \%$ no interestadual e $4,7 \%$ no internacional. Esses índices são cinco vezes mais elevados quando se referem à vitimização de parentes e amigos nos mesmos serviços: 25\% sofreram roubos no transporte intermunicipal, $27,2 \%$ no interestadual e $28,7 \%$ no internacional (Abrati, 2008).

A distribuição nacional dos roubos mostra que estes praticamente desapareceram em São Paulo e Rio de Janeiro, estados pioneiros e campeões desse tipo de delito entre as décadas de 1970 e 1990, mas o índice continua elevado em estados menos desenvolvidos da federação. É assim que Minas Gerais, Bahia, Goiás, Pernambuco, Alagoas, Maranhão e Pará passaram a concentrar, até 2007, a maior parte das ocorrências (Idem). Ainda que esses valores sejam inferiores aos apresentados pelas secretarias estaduais de Segurança Pública, como a da Bahia (SSP-BA, 2007), os dados confirmam a "migração" inter-regional do delito por razôes que ainda precisam ser investigadas.

Quanto ao estado da Bahia, que possui a segunda malha rodoviária do país depois de Minas 
Gerais, ${ }^{7}$ ele ocupou a liderança dos roubos a ônibus em rodovias entre 2000 e 2006, mas foi ultrapassado por Minas Gerais em 2007, voltando a recuperar o ao primeiro lugar, em termos absolutos, em 2013. Efetivamente, nas rodovias da Bahia houve pelo menos um roubo a cada dois dias entre 2003 e 2007 (Abrati, 2008; PRF, 2010). Duas décadas depois do Rio de Janeiro, a Bahia teve uma onda de roubos a ônibus em rodovias que elevou as taxas desse delito de 4,1\%, em 2003, para $6,97 \%$, em 2004, e 6,26\%, em 2005, por mil viagens. Nos anos seguintes, entre 2006 e 2007, as taxas caíram para $5,08 \%$ e $4,41 \%$ respectivamente, mas permaneceram acima do percentual inicial da série. Conquanto a falta de informação acerca do número de viagens interestaduais tenha impossibilitado o cálculo de taxas entre 2008 e 2013, os números absolutos ${ }^{8}$ evidenciam a ocorrência de mais de um roubo a ônibus por dia nesse período. Por sua vez, a multiplicação desses números de assaltos anuais pelo número médio de passageiros por veículo $(34)^{9}$ mostra que somente em 2013, ano em que ocorreram 524 eventos, foram roubados 17.816 passageiros. Em suma, os roubos seguem sendo um risco crônico desse tipo de transporte no estado da Bahia.

\section{Trabalho de campo}

Para este estudo exploratório qualitativo, optou-se pela triangulação de dados provenientes de diferentes fontes, categorias de entrevistados e instrumentos: análise textual, questionários e entrevistas. Estes dados foram colhidos em dois momentos distintos: de janeiro de 2008 a outubro de 2010 (Viodres-Inoue e Paes-Machado, 2010) e entre janeiro e agosto de 2015. No primeiro período, os pesquisadores coletaram matérias jornalísticas, aplicaram um questionário a um grupo de policiais rodoviários e realizaram 25 entrevistas semiestruturadas - quinze com rodoviários e dez com passageiros. No segundo momento, foram feitas mais 26 entrevistas: vinte com rodoviários e seis com passageiros, visando o aprofundamento e o detalhamento do conhecimento obtido na primeira etapa.
A pesquisa textual buscou conhecer a evolução, os contextos e as modalidades dos roubos a ônibus no país e, em particular, no estado da Bahia. Para isto, foi analisado um banco de notícias com 136 matérias da Folha de S. Paulo, entre 1971 e 2009. Outro recurso auxiliar na complementação de dados foi um questionário autoaplicável respondido por 41 policiais rodoviários e militares que participaram de dois treinamentos oficiais. Os dados contribuíram para entender as condições das estradas, os locais com maior frequência de delitos (hot spots) e as características dos autores dos roubos.

As entrevistas foram realizadas com rodoviá-rios (motoristas e cobradores) e passageiros. $\mathrm{O}$ critério da saturação de dados foi utilizado para definir o número de participantes. A amostra foi composta por rodoviários convidados a participar do estudo por abordagem casual pelos pesquisadores ou indicados, segundo a técnica da bola de neve, por outros entrevistados. Os eixos das entrevistas foram: a forma de roubo, o processo coercitivo, incluindo as açōes e reações de vítimas e infratores, e as práticas de segurança adotadas. As entrevistas transcorreram no Terminal Rodoviário de Salvador e em estaçôes de outras sete cidades do estado, nos veículos em viagens, em três garagens e em seis residências de rodoviários. As entrevistas duraram de vinte minutos a uma hora: uma parte foi registrada no gravador; outra, no Diário de Campo. A variação na duração é justificada pelas interrupções causadas por ruídos ambientais, imprevisibilidade das rotinas e irregularidade das pausas.

Os 35 rodoviários entrevistados tinham idade mínima de 28 e máxima de 61 anos (mediana de 38 anos). Todos sofreram tentativas de assalto ou foram assaltados, de uma a sete vezes, na condução dos ônibus. Com respeito aos dezesseis passageiros entrevistados, selecionados por indicação de contatos das redes dos pesquisadores, todos também foram vítimas de roubos a ônibus. A idade mínima deles era de 23 e a máxima de 54 anos (mediana de 33 anos). Os textos, as anotações do Diário de Campo e as transcriçôes de entrevistas foram analisados para criar agrupamentos conceituais e recortes temáticos. 


\section{Um retrato dos assaltantes de estrada}

Os assaltantes atuam nos acessos e nas proximidades de cidades e povoados do estado, ou por falta de outras oportunidades ilícitas (Cloward e Ohlin, 1960) ou por não quererem ser identificados em seus locais de moradia. A mola propulsora do seu empreendimento ilegal e violento (Hobbs, 1988; Volkov, 2002) é a receptação de mercadorias roubadas por redes de consumidores, comerciantes e outros agentes que buscam reduzir custos ou acumular capital pelo agenciamento da força (Zaluar, 1994; Paes-Machado e Riccio-Oliveira, 2009; Telles, 2010). Assim, dada a gama de bens de consumo valorizados equipamentos eletrônicos, relógios, joias, roupas e calçados de marca, etc. -, essas redes definem tanto os produtos desejados, como os métodos e técnicas específicas de roubá-los (Deakin et al., 2007).

Tal como o homem pecuniário e o delinquente ideais, os mandantes e executores dos roubos instrumentalizam, de forma inescrupulosa, bens e pessoas para seus próprios fins, manifestando crassa indiferença pelos sentimentos e desejos dos outros (Veblen, 1924). Isso pode ser observado nas atitudes de um bando de assaltantes em relação às vítimas de um capotamento de ônibus por eles provocado:

Depois que capotamos, lá estavam eles com os rostos cobertos com máscaras ou toucas pretas, a quebrar janelas, puxar as pessoas pelas roupas e cabelos, e a gritar para sairmos do carro ou eles colocariam fogo. Gritávamos que tinha gente ferida e morta e eles gritavam saiam "desgraças". Não sabíamos o que fazer [...] resolvemos sair e deixar nas mãos de Deus (lojista, 52 anos).

Se este e outros ataques provocam tais acidentes, isto não é nenhum problema moral para os assaltantes de estrada. Atuando sob o imperativo da obtenção de resultados financeiros, os infratores vão saquear suas presas no fundo do barranco em que despencaram. Eles não se sensibilizam com o pedido de socorro e o clamor apavorado dos passageiros agonizantes nas ferragens; enxergam apenas as metas por cumprir.

Efetivamente, os assaltantes de estrada são heterogêneos quanto à organização, ao número de pessoas envolvidas, aos tipos de armas e meios de transporte e ao profissionalismo. Ao lado de duplas ou trios de assaltantes avulsos - "pés de chinelo" na nomenclatura policial -, há quadrilhas que agregam número maior de integrantes. Tais quadrilhas, por sua vez, são diferenciadas em termos de habilidades gestoras (Gill, 2000; 2001; Letkmann, 1973) e de cooperação técnica (Aquino e Sá, 2014). Esta inclui as atividades de inteligência ao longo dos itinerários ou dentro dos ônibus por assaltantes infiltrados, visando colher, transmitir e processar informaçôes acerca de percursos, horários, poder aquisitivo dos passageiros e condições de vigilância dos veículos. Em contraste com os avulsos que portam facas, facōes, revólveres 38 (e até velhas espingardas de caça) e deslocam-se em carros velhos, motocicletas, animais de carga e mesmo a pé, as quadrilhas possuem escopetas, metralhadoras e carros mais novos.

Quanto aos modos de atuação, eles se aproveitam do seu conhecimento das vantagens ecológicas (St. Jean, 2007) da malha rodoviária, como trechos isolados, desvios, atalhos, etc., para atacar os ônibus predominantemente à noite e de madrugada - e, em parte dos casos, também desviá-los de seus percursos. Tais vantagens para o crime são maximizadas pela inexistência de sinal de celular, que poderia proteger tripulantes e passageiros na maior parte das rodovias. Ademais, a dificuldade de policiamento nas estradas e a falta de autoridade regulatória estatal (Roitman, 2004) - expressada na inoperância e mesmo cumplicidade de agentes públicos locais - favorecem os delitos. De modo geral, os assaltantes avulsos e as quadrilhas menos profissionais (Matthews, 2002) direcionam suas açōes para roubos a ônibus - comerciais e executivos ${ }^{10}-$ na própria estrada; as quadrilhas profissionais, por sua vez, roubam preferencialmente veículos executivos mediante o desvio de percurso, confinamento e saque dos tripulantes e passageiros.

\section{Fases da vitimizaçáo}

A vitimização por roubos a ônibus implica em tarefas específicas conjuntas para assaltantes e vítimas e desenvolve-se em cinco fases distintas, 
mas parcialmente sobrepostas, a saber: (a) captura do veículo; (b) compartilhamento da definição de situação de roubo entre assaltantes e motoristas; (c) compartilhamento da definição de situação de roubo entre assaltantes e passageiros; (d) roubo; (e) libertação.

\section{Captura do veículo}

Após serem selecionados, segundo critérios que não serão discutidos aqui, os ônibus são abordados por assaltantes posicionados em lugares e momentos adequados para capturá-los mediante táticas violentas ou não. As táticas não violentas compreendem a simulação da aparência de normalidade (Jacob, 2012, 2013) pelo ingresso de assaltantes embarcados como passageiros e falsas operações policiais e os bloqueios das vias. Por sua vez, as táticas violentas envolvem ataques rápidos e repentinos (blitzes) (Jacobs, 2013) contra os veículos. Ao mesmo tempo que tais ataques amplificam a violência física e psicológica no momento que precede ou acompanha o estabelecimento da copresença, eles influenciam a percepção de medo dos motoristas e dos passageiros acordados dentro do ônibus.

A infiltração dos ônibus por assaltantes embarcados como passageiros (Paes-Machado e Levenstein, 2004) é uma forma de simulação ou gerenciamento da normalidade que visa reduzir a distância em relação ao alvo sem alertá-lo prematuramente, nem levá-lo a impedir o encontro coercitivo (Jacobs, 2012, 2013; Copes et al., 2012 ). Essa ilusão é criada pelo ingresso no veículo de assaltantes sozinhos, em duplas ou trios, às vezes acompanhados por mulheres e crianças, como usuários comuns, quando na verdade buscam melhores oportunidades para agir (Copes et al., 2012). Uma vez no ônibus, eles procuram poltronas que dão maior visibilidade, verificam a presença de policiais ou vigilantes e aguardam o momento e o lugar certos para o anúncio do assalto. No caso de roubos com desvio do veículo, que demandam mão de obra adicional, outros infratores embarcam posteriormente ou aguardam no trecho combinado para pará-lo ou desviá-lo do percurso.
Tinha um passageiro no ônibus que do nada começou. Todo mundo dormindo. Só ouvi o grito: "Bora, é assalto!". Rapaz, eu "gelei" na hora. O cara ali, vindo durante a viagem. Eu "fiquei na minha”. A perna tremia, mas fazer o quê? Eu não podia parar. Só vi ele dizendo pra todo mundo ficar quieto. Aí já viu. Mandou adiantar. "Se der sinal eu mato. Tem uma galera comigo". Chegou em um ponto e ele mandou entrar em uma estrada de terra. Ele estava muito nervoso. Até que depois de alguns metros eu vi um carro. E mais três pessoas. Todos armados. Parei e abri a porta (motorista, 35 anos).

A segunda forma de simulação de normalidade são as falsas operações policiais nas estradas. ${ }^{11}$ Trata-se de uma tática ousada, mas pouco frequente, em especial na Bahia, por talvez demandar equipamentos expressivos padronizados (Goffman, 1975 ) e escassos, como viaturas e uniformes. A credibilidade dos elementos da encenação - homens fardados, falsa viatura policial etc. - garante que a captura do veículo não seja desafiada. Tal como os falsos passageiros, a eficácia dessa técnica está fundada em uma ação falaciosa, em que se blefa com o processamento esquemático dos alvos e se ganha tempo com a promoção do equívoco de avaliação (Paes-Machado e Nascimento, 2014).

Entre essas técnicas de simulação da normalidade e os ataques rápidos e repentinos há o bloqueio de trechos em que a cobertura da rodovia é satisfatória ou em trechos esburacados e vias sem pavimentação. As barreiras mais utilizadas são troncos de árvore, pedras, objetos perfurocortantes e veículos:

Eu estava trafegando na estrada... os bandidos colocaram pedaços de madeira, troncos grandes de árvore na estrada, quando dei por mim, já estava em cima, era de noite; quando freei, quatro bandidos surgiram do meio do mato anunciando assalto" (motorista, 52 anos).

Trata-se de fazer o motorista frear o veículo e ficar ao alcance de infratores que aguardam, emboscados nas margens da estrada, a oportunidade para rendê-lo: 
A., motorista, 44 anos, 'topou' com um trio de assaltantes que colocou pedras na pista e logo que o ônibus parou, atirou no para-brisa. Conduziram o ônibus para um matagal e durante duas horas agrediram e saquearam os passageiros" (Viodres-Inoue e Paes-Machado, 2010, p. 12).

Os assaltantes também espalham na estrada objetos perfurocortantes, chamados de miguelito ou pé de galinha, para furar os pneus dos ônibus:

Eles usam umas armadilhas. Já vi colocar fruta na estrada. Você passa e pronto. Quando vai ver tem ferro dentro, prego, sei lá. Só sei que quando senti, foi o pneu vazio. Parei, fui olhar, desci. Demorou um pouco, passou um carro. Quando os caras saíram, eu já sabia. Atiraram logo, de longe, mas não pegou no ônibus. [...] Mandaram eu andar e entrar numa estrada, ali mesmo. (motorista, 32 anos).

O bloqueio ainda pode ser efetuado com veículos pequenos ou grandes. É o que sucede nos roubos "casados" ou em cadeia, em que carretas ou ônibus já tomados para saque são empregados para bloquear outros ônibus. Esta forma de bloqueio atingiu até veículos que viajavam, por medida de segurança, em comboio (Folha de S. Paulo, 20/5/2004). Em certos casos, enquanto os passageiros permanecem confinados nos desvios das rodovias, outros ônibus são parados para igualmente serem saqueados (Francisco, 2003; Viodres-Inoue e Paes-Machado, 2010, p. 12).

No segundo assalto sofrido pelo motorista A. (44 anos), às $00 \mathrm{hs} 30$, seis pessoas armadas [pistola calibre 12] pararam o ônibus no quebra-molas e o conduziram para o matagal. O motorista ficou no seu assento, os passageiros foram revistados, o motorista foi poupado. Usavam máscaras, comentaram que em seguida viria um ônibus da mesma empresa que também seria saqueado. Parte do bando ficou e o restante foi abordar o outro veículo. Os assaltantes que saíram trouxeram o outro ônibus e repetiram o procedimento. $\mathrm{O}$ confinamento só foi encerrado às cinco da manhã (Inoue-Viodres e Paes-Machado, 2010, p. 13).
Os ataques rápidos e repentinos são mais visíveis e ameaçadores (Jacobs, 2013) que a simulação da normalidade e o bloqueio das vias. As suas formas, porém, variam conforme a velocidade do ônibus. Nos momentos de baixa velocidade ou parada do veículo no acostamento da estrada, o motorista fica ao alcance e pode ser facilmente rendido pelos assaltantes:

Quando cheguei às proximidades de Ipirá, um colega que saiu em comboio comigo, na frente, parou no acostamento. Ele parou, encostei-me ao fundo e parei. Foi quando fui rendido por três elementos que já tinham assaltado ele. Eles entraram com muita violência. Apontaram as armas e eu abri” (motorista, 27 anos).

Nos momentos de maior velocidade, os assaltantes utilizam objetos contundentes e tiros para capturar o veículo. Por mais rudimentar que pareça, o arremesso de pedras nos vidros dos ônibus (Polícia Rodoviária Federal, 2010) é um dos procedimentos empregados nos ataques. A depender da velocidade do ônibus, do ângulo de lançamento e da pontaria, as pedras podem errar o alvo, dando chances ao motorista para escapar (Felson, 2006; Paes-Machado e Riccio-Oliveira, 2009).

Eu estava passando [de] noite também. De repente ouvi um barulho no teto [do ônibus]. Como se um animal tivesse caído. O pessoal todo acordou com o barulho. Eu me mandei dali. Parei num posto de combustível [...]. De repente um caminhoneiro falou que o teto estava amassado. Rapaz, quando eu vi, tomei um susto. Imagina o tamanho da pedra. Então o segurança [do posto] falou que eles faziam isso. Que era a terceira vez naquele dia. Eles ficam no alto de um morro, jogando o pedregulho. Já pensou se pega no para-brisa? Eu seria história agora. Mas ele disse que se eu parasse, sobrava (motorista, 42 anos).

Mais perigoso do que o arremesso de pedras são os disparos de tiros nos pneus ou no para-brisa dos veículos, por assaltantes posicionados nas margens e no meio da pista, ou pilotando automóveis: 
"Atiraram no pneu do ônibus e ele parou. Quando acordamos, o ônibus já estava em uma ribanceira [...]. Ele [o motorista] entrou nesse lugar, onde eles [os assaltantes] pediram" (estudante, 23 anos). Acontece que mesmo sob o fogo de disparos há motoristas que utilizam o veículo, como arma e escudo (Jacobs, 2012, 2013), para atropelar assaltantes e se proteger dos tiros. ${ }^{12}$

L. relata que, por volta de 1 h30 da manhã, um homem com máscara e armado ficou na frente do veículo. Pensou se deveria parar ou seguir em frente: tomou 'a decisão de seguir e se preciso passar por cima do assaltante’; abaixou a cabeça e pediu que o motorista que o acompanhava na cabine fizesse o mesmo e seguiu em frente. ' $\mathrm{O}$ assaltante saiu da pista, mas desferiu três tiros, nenhum atingiu o veículo’. O rodoviário pediu que todos afivelassem os cintos porque seria preciso seguir a viagem com maior velocidade (Inoue-Viodres e Paes-Machado, 2010, p. 13).

Os ataques praticados por assaltantes motorizados, que imitam cenas de cinema, são especialmente amedrontadores:

Aí [à noite] cada carro que você vê se aproximando é o coração batendo forte. Você torce para não ser nada. $\mathrm{O}$ carro vem e você torce. Quando ele passa dá aquele sossego. Mas é tensão a noite toda. Você tem que se preocupar com o volante, estrada e vagabundo (motorista, 37 anos).

Segundo esse procedimento, carros seguem sem ultrapassar, mesmo que o condutor do ônibus sinalize para que o faça. No trecho escolhido para praticar o roubo, os assaltantes emparelham seu veículo com o ônibus e atiram neste para o motorista parar:

Vi dois carros se aproximando. Eu estranhei porque não é comum ter muita gente na pista naquele horário [2, 3 horas da manhã]. Senti medo. Eles vieram e o primeiro carro passou e já foi atirando. Foram dois tiros e eu joguei o carro para fora da estrada. Eles pararam lá na frente, longe mesmo. E o outro carro parou atrás. Mandaram eu abrir a porta e começaram o assalto (motorista, 45 anos).

Caso o rodoviário desobedeça, os infratores fazem novos disparos contra o veículo (Folha de $S$. Paulo, 7/1/1987, 24/11/2007) que podem redundar, nesta fase inicial de estabelecimento da copresença, em desfechos desastrosos (Linger, 1992) para o veículo e seus ocupantes:

$\mathrm{Na}$ madrugada acordamos com um barulho seguido que parecia peças se soltando do ônibus e em meio a gritos ouvi meus colegas falarem: 'É tiro na direção do ônibus!'. O motorista aumentou a velocidade, eram dois carros com quatro homens, tinham sinalizado para o motorista parar, como não parou e começaram a atirar. $\mathrm{O}$ motorista acelerou, não conseguiu se livrar deles até que capotou duas vezes em uma ribanceira e ficou com as rodas para cima (lojista, 52 anos).

Em suma, se várias táticas não violentas adiam por algum tempo o momento do compartilhamento da definição de situação de roubo, os ataques deixam claras as intenções dos infratores (Jacobs, 2013) ou antecipam este compartilhamento. Daí sua importância para a obtenção, nesta fase inicial (the onset) e crítica do encontro predatório (Lindegaard et al., 2015; Copes et al., 2012), da aceitação dos motoristas.

\section{Compartilhamento da definição de situação de roubo entre assaltantes e motoristas}

O compartilhamento da definição de situação de roubo será bem-sucedido quando os motoristas demonstrarem que perceberam o que está em jogo e entenderam seu papel no evento (Idem). Conquanto o uso da violência física esteja muito presente, a violência psicológica para aumentar o medo é a mais mencionada pelas pessoas.

Após pararem o ônibus, os infratores aparecem disparando para o ar ou apontando suas armas para o rodoviário abrir a porta e eles adentrarem no veículo. Trata-se de fazê-lo compreender o objetivo da ação e o risco de resistência, transmitindo a ideia de que a morte é iminente (Wright e Decker, 1977; Copes et al., 2012): 
Os bandidos começaram a bater na porta do ônibus e apontaram a arma para o motorista. Disseram que se ele não abrisse a porta o matariam. Então o motorista abriu a porta... eles entraram, colocaram a arma e... pediram para o motorista seguir o carro [na direção do desvio] (assistente social, 43 anos).

Em certos casos, em que os rodoviários resistiram a parar o veículo na fase da captura, o veículo, a situação de roubo é explicitada por tapas e coronhadas:

Um [assaltante] desceu da moto e entrou no carro, no ônibus. O outro ficou na moto. Eu abri a porta e ele foi entrando. Aí veio falando: fica caladinho senão lhe desço a mão. Me deu um tapa (motorista, 42 anos).

Em contraste, há compartilhamentos em que os infratores buscam a tranquilização: "Ah... eles mandavam eu ficar tranquilo, que ninguém iria fazer nada com ninguém, que era pra seguir as ordens deles que tudo sairia bem" (motorista, 52 anos).

Permeando a recepção da mensagem transmitida pela arma de fogo, o conhecimento acumulado, direto ou indireto, dos rodoviários torna-os perfeitamente cientes da natureza desses encontros. Entre outras coisas, aprenderam que os assaltantes de estrada estão dispostos a tudo para lograrem suas metas, que "não aliviam", nem "liberam nada": "Eles batem, xingam, empurram [...]. Eles não liberam nada. Se você der um vacilo, eles batem mesmo" (motorista, 45 anos). Também aprenderam a reconhecer as diferenças de habilidade (Gill, 2001) gestora entre assaltantes "inexperientes" e "profissionais do crime". Enquanto os primeiros são definidos como jovens, nervosos (ou agindo sob a influência de drogas) e violentos, ${ }^{13}$ os "profissionais" caracterizam-se pela frieza e polidez no trato (Paes-Machado e Nascimento, 2011). Associado a isto, os profissionais se destacam por sua capacidade de influenciar a psicologia da vítima: "Do jeito que eles agiam, na tranquilidade, era de quem trabalhava com isso. Sabem mexer com o psicológico da pessoa" (motorista, 43 anos). Consequentemente, os rodoviários sentem-se mais seguros e, certamen- te, dispostos a cooperar nos roubos conduzidos por profissionais do que nos ataques cometidos por assaltantes inexperientes: "Quando é um assalto dessa maneira [profissional] não é bom, porque a gente não sabe o que está acontecendo lá dentro [na ala dos passageiros]. Porém dá mais segurança pra gente" (motorista, 45 anos). Ou seja, diferente do estilo espasmódico e truculento dos amadores, a gestão de vítimas (Letkmann, 1973) pelos profissionais é mais comedida no uso da força para a manipulação do medo, apostando na resiliência, preservando o potencial cognitivo e alargando a margem de colaboração dos assaltados.

Embora a meta sejam os pertences dos passageiros, o rodoviário percebe-se como o alvo principal da ação, não só por ser o responsável pelo veículo - "o ônibus está comigo, então eu sou o alvo" (motorista, 35 anos) -, mas também por passar mais tempo sob a mira da arma (motorista, 42 anos). A ação coercitiva se manifesta, neste ponto, em uma performance curta e grossa de inversão do papel de autoridade: aquele que até então era o condutor passa a ser conduzido, perde sua posição de comando e é forçado a tomar o lugar de comandado (Paes-Machado e Levenstein, 2004):

Tentamos manter a calma, mesmo diante da situação. Eu tento passar para o indivíduo que ele é o dono da situação. Eu falo: 'estou para fazer o que você quiser, só não me machuque'. Dizemos que temos família e tal. Transmitimos que ele está no controle da situação (motorista, 27 anos).

O próximo passo é executar as tarefas esperadas e ser uma espécie de coorientador na dinâmica grupal de vitimização, entrando em cena com as atuaçôes necessárias e o repertório de condutas assertivas. Além de franquear o acesso dos infratores ao interior do ônibus, estas tarefas incluem, no caso dos roubos com desvio de percurso, a condução do veículo e a abertura do bagageiro. Daí a tentativa de adaptação do condutor a este novo papel: "eu fico quieto, na minha, eu estou fazendo o meu trabalho, deixo eles fazerem o deles lá" (Inoue-Viodres e Paes-Machado, 2010, p. 13).

Nada disso é tranquilizador: 
Quando o assalto é em movimento, eles pedem para darmos o mínimo de sinal [...]. Isso é complicado porque não tem como dirigir, fazer uma ultrapassagem sem fazer sinal. Eles pedem para aumentar a velocidade, ao mesmo tempo pedem para diminuir. Eles ficam meio desequilibrados. Meu maior medo é um acidente fatal. A arma disparar e morrermos"(motorista, 27 anos).

Qualquer incompreensão a respeito do cumprimento dessas ordens é pronta e duramente punida, como sucedeu com um motorista que recebeu uma coronhada na nuca, com afundamento ósseo, por parecer que estava sinalizando e, em seguida, passou a temer pela vida:

No carro tem duas luzes, em cima da gente, na cabine. Quando eles entraram, o 'Resta' [um dos assaltantes], disse que estava piscando. Ele me agrediu achando que eu estava dando o sinal. Eu falei 'Rapaz, eu não estou dando sinal não'. Mas ele meu deu uma coronhada. Mandou eu adiantar. [...]. Eu achei que ele iria me matar naquele momento (motorista, 35 anos).

Ademais, os motoristas temem catástrofes potenciais (Copes et al., 2012) ou desfechos desastrosos (Linger, 1992) provocados por incompreensões mútuas e açôes imprevisíveis. Se esta possibilidade está presente nos roubos ordinários de um ou poucos indivíduos (Copes et al., 2012), o que dizer acerca de roubos inéditos como estes que atingem simultaneamente uma média de trinta pessoas de cada vez?: "Eles [os assaltantes] avisam: 'Olha, se fizer qualquer gracinha eu mato todo mundo'. Então você fica naquela tensão, para que ninguém faça nada" (motorista, 32 anos). $\mathrm{Na}$ espiral de violência observada nesses roubos e nas táticas de combate (Paes-Machado e Levenstein, 2004), passageiros armados, em especial policiais contratados ou não como vigilantes pelas empresas, efetuam disparos que provocam ferimentos e mortes de infratores, outros ocupantes do veículo e dos próprios policiais:

Quando chegou em X, dois elementos pegaram o carro e anunciaram o assalto. Depois de saquearem os passageiros, eles se deram mal. No fundo do ônibus haviam dois policiais que reagiram e balearam os dois [que] vieram a óbito: 'Se deram mal dessa vez' (motorista, 27 anos).

Os disparos desencadeiam pânico e fugas desastrosas do ônibus:

Eu acho que é pior [do que a situação do passageiro] porque nós estamos dirigindo, entendeu? Então o medo que ficamos é de um passageiro reagir ou passar uma viatura no momento e eles trocarem tiro. Você não sabe a reação que ele [o assaltante] vai ter em um fogo [tiroteio] para cá. Porque para sair do carro só tem uma porta, com você lá na frente (motorista, 35 anos).

Enfim, em contraste com empregados vítimas de roubo a banco, que são tratados como estorvos a serem removidos ou neutralizados pelos assaltantes (Einstadter, 1966), a participação dos motoristas rodoviários é fundamental, e não é à toa que eles se percebem como o alvo principal da violência física e psicológica nessa etapa.

\section{Compartilhamento da definição de situação de roubo entre assaltantes e passageiros}

Após o estabelecimento da coorientação de roubo entre os assaltantes e o motorista, os primeiros viram a página do script (Copes et al., 2012) para incluir e tornar os passageiros protagonistas de uma cena da vitimização. Sem excluir a violência física, essa cena compreende a amplificação da coação psicológica contra eles, em especial, nos encontros predatórios que envolvem o desvio de percurso do veículo e o confinamento de seus ocupantes.

Devido à porta divisória da cabine do motorista, é comum os passageiros não se darem conta do que está acontecendo; às vezes estão simplesmente dormindo (Folha de S. Paulo, 24/5/1985, 14/12/1988). Para assegurar que todos entendam a situação (Copes et al., 2012), parte dos assaltantes ingressa com armas em punho na ala dos passageiros. ${ }^{14}$ É o momento de todos saberem, por um ato de simplificação cognitiva, típico de algumas performances (Alexander, 2004), que são o alvo da ação coercitiva: “'Isto aqui é um assalto!', brada alguns 
dos prepostos, xingando e, às vezes, distribuindo tapas nos mais sonolentos e atirando no piso do veículo. A linguagem intimidadora dramatiza, de modo inequívoco, a mudança repentina e irreversível da situação em um crime (Katz, 1988). Os passageiros são transportados para o pesadelo da opressiva situação de assalto, quando também podem esboçar reações mal recebidas pelos infratores. "É a hora do espanto, da gritaria e do pânico" (lojista, 52 anos).

No entanto, como descargas emocionais se opóem à ideia de controle inquestionável da cena (Copes et al., 2012), os assaltantes pedem ou ameaçam os presentes para se calarem:

As pessoas começaram a gritar, mas os bandidos pediram pra ninguém gritar, pois se tratava de um "assalto, e que eles não iriam fazer nada com ninguém, que eles só queriam dinheiro e objetos de valor (motorista, 52 anos).

Intensificam também a pressão sobre um ou outro tripulante ou passageiro para conter a inquietação reinante:

O cara [o assaltante] chegou falando que é assalto, aí ele mandou ficar com a mão na cabeça e os olhos fechados. Uma moça nervosa, ela ficava tremendo o olho sem conseguir fechar, e ele [o assaltante falando] 'você tá me olhando?' (professora, 33 anos).

Com ou sem panos amarrados no rosto, máscaras ou capuzes, os infratores costumam ordenar que os passageiros não olhem para eles ou fiquem de cabeça baixa. De um lado, as máscaras, assim como a destruição de câmeras internas de filmagem, viabilizam o anonimato (Huggines et al., 2006), dificultando identificações e reconhecimentos:

[Os] cinco assaltantes falavam pouco, estavam todos mascarados, não dava nem pra ver a cor da pele deles, estavam de casaco, uns de camisa amarrada [no rosto], outros de brucutu, pareciam pessoas da roça, bem de interior (professora, 33 anos).
De outro, restringe o campo de percepção da vítima, impossibilitando-a de se orientar. A ordem de abaixar a cabeça é um gesto despótico que serve para reforçar a hierarquia do mando e da obediência, mostrando quem tem o poder para controlar e punir.

Outrossim, a suspeita de que os assaltantes possam estar drogados contribui para aumentar o medo. A aparente ausência de racionalidade gera tanto pavor que as vítimas se submetem a qualquer coisa, pois não têm ideia do que pode acontecer. Mas, para evitar que esta conduta expressiva comprometa a orientação racional-instrumental do roubo, ela é refreada, em várias equipes, por parceiros equilibrados ou profissionais:

O cara parecia que estavam com o capeta no corpo, drogado mesmo, ele dava tapas na cabeça das pessoas e xingava palavrão, mas tinha outro que era mais equilibrado, ficava controlando às vezes os parceiros (motorista, 49).

Contudo, como nem sempre a encenação toda impede que alguns passageiros percam o controle, tendo crises de choro, segurando seus pertences etc., eles são punidos. Com isso, estabelece-se uma espécie de pacto psicológico que é a essência mesma da transação coercitiva: se não houver oposição, todos ficarão ilesos, caso contrário, serão mortos ou machucados. Tal pacto, entretanto, não é fixo. Ele é constantemente renovado pela reiteração das ameaças seguida por demonstrações de aceitação. Dado o caráter incerto do encontro predatório (Copes et al., 2012), o sucesso deste depende, em grande medida, dessa intermitência de estímulos e reforço para promover a sensação de medo (Jacobs, 2013) e dificultar a retomada de agência das vítimas:

[Eles faziam ameaças] pra que ninguém reagisse mesmo, esses caras ficam com medo de alguém tentar alguma coisa, de ter algum passageiro armado. É uma incerteza, eles não sabem no que vai dá o assalto. Pode dá certo ou não (motorista, 41 anos).

Afora isso, pode-se supor que as ameaças intermitentes operam como lembretes e chamamentos 
para os próprios assaltantes, no sentido de ficarem de prontidão ou alertas para os desafios cambiantes das cenas e das circunstâncias.

Simultaneamente, os infratores fazem a triagem das vítimas. Passageiros do sexo masculino são inspecionados e podem ser, caso pareçam policiais, agredidos para confessarem sua identidade profissional. Quando isso é constatado, eles são imobilizados ou desarmados. ${ }^{15}$ Mais uma vez, o caráter transgressivo desse delito de contato direto entre infratores e múltiplas vítimas se expressa em uma performance de inversão dos papéis de autoridade. Tal exibição envolve a apropriação jocosa e simbólica das insígnias e das prerrogativas daqueles que deveriam ser objeto de deferência de todos e de temor, da parte dos infratores:

Eles renderam primeiramente o policial, tomaram a farda, o boné e arma que ele portava; aí um deles vestiu a farda, colocou o boné e a arma, e disse: 'agora eu vou brincar de ser policial, quem manda aqui agora sou eu' (comerciante, 33 anos).

Doravante não há mais nenhum entrave para a concretização do plano delituoso.

Nos roubos sem desvio de itinerário, o enquadramento das vítimas é seguido imediatamente pela tomada efetiva dos bens por um assaltante ou mesmo um passageiro convocado para a tarefa:

Geralmente quando há uma arma, você sabe né? O medo é a primeira coisa que vem, as pessoas ficam estáticas... feito estátuas. Ninguém reage e tampouco tenta negociar dizendo que não tem dinheiro ou celular. Entregam tudo! (cobrador, 42 anos).

Conquanto esta receita rápida e certa de manipulação do medo garanta a colaboração da maioria, ela não funciona para alguns passageiros, que podem, consequentemente, ser punidos por resistirem a entregar seus pertences. Enfim, após a limpa, os infratores fogem, abandonando as vítimas em sua rota de viagem. ${ }^{16}$ Em contrapartida, os roubos com desvio de percurso demandam mais tempo, critério e encenação. No trajeto para o cativeiro final, en- quanto um assaltante orienta o motorista, outros fazem a segurança do recuo, devendo acionar os parceiros em caso de ameaça. Nas investidas mais complexas ou delicadas, sentinelas (Hallsworth, 2005) próximos da rodovia estão instruídos para usar assovios, sinais de lanternas, fogos de artifício e tiros para o alto para avisar os membros do grupo sobre a aproximação de terceiros. O cuidado não é excesso de zelo; várias empresas de transporte contratam escoltas motorizadas de vigilantes armados para proteger seus veículos (Roitman, 2004), além do que o deslocamento do ônibus de seu trajeto original já pode ter sido notado por motoristas de carros comuns.

À medida que o veículo se afasta da rodovia, as vítimas sentem-se mais desamparadas, aumentando a sensação de vulnerabilidade. As estradas de terra, às vezes com barrancos e quase que encobertas pela vegetação silvestre, são um teste para o motorista, que dirige de farol baixo ou luzes apagadas. Passageiros amedrontados desafiam a ordem de permanecer de cabeça baixa, olhando pela janela à espreita de algum sinal de proteção. A escuridão reflete a falta de esperança, pois sabem que nas "margens do Estado" (Das e Poole, 2004) para onde estão sendo levado não há guardiãos capazes de protegê-los (Cohen e Felson, 1979):

Durante a noite [o assalto] é um pouco pior, porque tudo é mais complicado. A sensação de pânico, de terror é um pouco pior. Durante o dia dá a sensação de que você está sendo visto, que alguém esteja vendo e denuncie. Uma esperança... (motorista, 25 anos).

Quando o veículo enfim estaciona, o pânico já tomou conta da situação.

Roubo

A transferência (Luckenbill, 1982) ou a apropriação de bens, que começa e acompanha o compartilhamento da definição de situação de roubo e, em parte dos casos, termina na estrada, prossegue nos locais onde os veículos desviados são estacionados e as vítimas ficam ainda mais à mercê da equipe coercitiva gestora. $\mathrm{O}$ gradiente de manipulação e a 
percepção de medo durante a apropriação - que se assemelha, pelas proporçôes materiais e características performáticas, a um saque - varia de acordo com o estilo de gestão menos ou mais violento das equipes e as reações dos assaltados.

A equipe opera mediante a participação dos seus membros nas tarefas de vigilância, revista, busca, coleta, triagem, carregamento, acondicionamento e transporte dos bens ${ }^{17}$ :

Eram três ou quatro dentro do ônibus e outros por fora também [...] eles começaram a revistar um por um, do começo ao fim. Foram pegando as coisas de todo mundo, aparelho eletrônico... Um revistava e outros dois desciam com as coisas (estudante, 23 anos).

Nas equipes mais estruturadas, por sua vez, observa-se uma diferenciação entre funções de comando e execução. Há líderes que acompanham as tarefas, cobrando agilidade dos comparsas e colaboração das vítimas (Luckenbill, 1981): “Vamos! Não adianta esconder, quero tudo!'. O da frente [assaltante] dizia para o outro:

Vamos ladrão, rápido, pega tudo, adianta ladrão!'. Não usaram nomes, só se tratavam por 'ladrão'" (lojista, 52 anos).

Se não deixam nem moedas de lado, pode acontecer de rejeitarem ou fazerem gozação com objetos pouco valiosos, como bijuterias, relógios e celulares antigos, entre outros objetos. ${ }^{18}$

Entretanto, a condução dessas revistas e buscas revela diferenças importantes nos estilos de gestão das vítimas (Letkmann, 1973). Em contraposição aos procedimentos mais leves ou aceitáveis das equipes profissionais - "Eles só ficavam passando a mão nos passageiros, procurando se a pessoa tinha escondido dinheiro ou objeto de valor. Sabe como é? Igual à revista da polícia" (motorista, 49 anos) -, as revistas e buscas pelas equipes amadoras são brutais e humilhantes, ${ }^{19}$ como se pode observar neste depoimento:

Mandaram eu descer. Me empurraram, caí no chão. Pisaram em minha cabeça. Depois foram descendo todos os passageiros. Se demorasse de descer eles batiam, empurravam. Aí veio o que estava no ônibus e mandou todo mundo deitar com o rosto no chão. Dois subiram e começaram a "limpar" o carro. Aí foram pegando e colocando tudo no carro. Depois desceram e foram pegando passageiro por passageiro. Colocaram tudo no carro e saíram. Foi muito ruim mesmo (motorista, 35 anos).

As diferenças entre os estilos de gestão das equipes também estão patentes nos modos de lidar com as reações de passageiros que de um lado, resistem ou demoram para entregar seus pertences, e de outro, atrapalham o script da cena. A resposta profissional ao que denominamos de resistência material - para diferenciar da física e da verbal (Block e Skogan, 1986) - ou recusa das vítimas em entregar seus bens (ou parte destes) é ilustrada pelo tratamento ministrado a um comerciante em viagem de compras que, embora tenha corrido para o mato com o dinheiro que carregava, foi recapturado sem represália (lojista, 52 anos). O estilo amador é exemplificado por dois outros casos que, ao contrário do anterior, foram violentamente castigados: um homem que ocultou seu celular barato embaixo do banco e teve que entregá-lo, depois de ser descoberto e de apanhar por isto, para evitar o pior (lojista, 52 anos), e outro que recebeu uma coronhada por ter ocultado o dinheiro entre os bancos do ônibus (motorista, 45 anos). Afora esses exemplos, foi citada a situação de uma senhora que, mesmo tendo desmaiado, quase foi despida à força para uma busca (motorista, 45 anos ).

Nessa mesma linha truculenta, os assaltantes agridem pessoas que demoram, por nervosismo, para abrir seus acessórios de viagem - bolsas, mochilas, valises - e disponibilizar seus bens. Ou seja, em lugar de alargar a margem de colaboração dos assaltados, o estilo amador gera emoções contraproducentes que fazem os assaltantes incrementarem, ao modo de um efeito pingue-pongue, o uso da violência física para obterem o que desejam, reestabelecerem a autoridade ou manterem a reputação (Jacobs, 2013):

Teve um passageiro que tentou reagir e apanhou muito mesmo. Esses vagabundos não aliviam. E 
ele fez errado, também. Nessas horas você não pode reagir, entende? Não que ele tenha reagido, mas foi "bater boca", falando demais, sabe? Mandaram ele abrir a mochila, algo assim. Mas ele não conseguia, não sei. Só sei que ele foi tentar explicar, pedir calma e os caras já foram batendo. Eu ouvia "Calma o quê, rapaz? Você está maluco? Perdeu a noção? Calma o quê?”. Aí foi pânico geral. Mulher gritava, homem gritava. $\mathrm{O}$ pessoal pedia para parar. Mas os caras não aliviavam $^{20}$ (motorista, 28 anos).

Apesar ou por causa de os assaltantes não poderem, por sua inferioridade numérica, evitar ou suprimir a resistência verbal forçosa e coletiva dos demais passageiros contra seus excessos, eles rechaçam a palavra do homem que insinua, no seu pedido de clemência e tentativa de abertura de diálogo, um protagonismo da vítima que precisa ser negado (Sykes e Matza, 2008). Há, ainda, os espancamentos de passageiros que não conseguem conter, mesmo quando advertidos, crises de choro suscitadas, exatamente, por essa amplificação do medo. Tal amplificação pode levar a um estresse agudo, com somatizaçôes, sentimentos de desrealização e despersonalização temporários (Fabião et al., 2008; Hollander e Simeon, 2006) que, por sua vez, intensificam a percepção das ameaças e dos perigos:

Eu fiquei muito nervosa e cheguei a perder os sentidos, eu caí literalmente, meu corpo formigava, eu tremia e ficava rezando ai meu Deus me ajuda a ficar em pé porque se eu cair ele pode achar que é reação e querer me matar. Ele [o infrator] estava com uma arma grande e era cruel. Ele ficava no lugar que tinha pedra, ele pisava e aquele barulho da pedra, [e eu] com o olho fechado [...] dava um sentido de pavor (professora, 33 anos).

Mas, voltando ao choro incontido, este manifesta sentimentos que tampouco são compatíveis com o script (Copes et al., 2012) dos assaltantes:

Todo mundo ficou deitado, e os outros cinco rapazes com as armas apontadas dizendo que iriam matar todos nós. Foi aí que 'bateu' o de- sespero. Imploramos, pedimos para eles não fazerem isso. Mas eles diziam coisas horrorosas. Tinha uma senhora operada dos seios e eles batiam [por conta de uma crise de choro] nessa senhora (estudante, 23 anos).

Novamente, o desespero somado com a superioridade numérica fazem com que os demais passageiros desafiem, até certo ponto, o frame coercitivo, elevando a tensão da cena e contribuindo, possivelmente, para respostas violentas adicionais.

Junto com a violência psicológica e física, a interação coercitiva agrega a ameaça do abuso sexual. Tal dimensão está presente e é facilitada quando os passageiros são obrigados a tirar parte ou toda a roupa na frente de todos (Paes-Machado e Levenstein, 2004; Folha de S. Paulo, 18/8/2006, 11/11/2008). Isso quebra a representação social do que pode ser mostrado em público (Goffman, 1975) e contribui para o sentimento de violação, sobretudo quando a revista envolve o apalpamento das partes íntimas femininas: "Um fez uma revista de rotina e o outro a gente considera que fez um abuso sexual, porque ele apalpou as partes íntimas da gente de forma contundente, acho que no sentido de humilhar a vítima, e ele era mais cruel" (professora, 33 anos). A exibição sarcástica e carnavalesca de roupas íntimas, por seu turno, derruba outras barreiras simbólicas que circunscrevem e protegem o corpo da violência (Caldeira, 2000): "De uma amiga minha tiveram a capacidade de levar tudo e só deixar uma calcinha e um sutiã assim no banco" (professora, 33 anos). A partir daí, o próximo passo é - sobretudo nos encontros em que os infratores mantêm até o final do assalto o controle inquestionável das circunstâncias (Copes et al., 2012) - o abuso sexual:

Eles "pegaram" uma moça, lá. Ela desceu com todo mundo, mas um deles mandou ela subir. $\mathrm{O}$ pessoal ainda reclamou, pediu para eles liberarem a moça, que ali todo mundo era trabalhador. A moça subiu [...]. Só depois que ela disse que ele pediu pra fazer nele você sabe... com a boca. Ela disse que pediu para eles não fazerem nada com ela, que não matasse. Foi o que ela contou [...]. Eles não respeitam homem, imagina mulher. Ela não fez nada. Mas ele estava querendo, e ela sobrou (motorista, 37 anos). 
Aqui a expressão do poder sofre uma mutação: do uso da força para a dominação, retomando as lentes weberianas. A força é explícita, masculina e muscular; eles lançam mão dela para provocar medo e demonstrar autoridade. Mas isso pode se transformar em um exercício cansativo que requer compensações. Nas apalpadelas e no estupro os assaltantes não precisam mais usar a força bruta, basta que mantenham uma atitude de dominação; o criminoso se sente Senhor, dominus, em latim. Seu poderio se dá por consenso e submissão. Exibir a calcinha é uma demonstração disso. E as vítimas certamente reconhecem tal simbolismo de autoridade. É nítida a alquimia psicossocial que ocorre nessa passagem: a força é empregada para a apropriação de bens materiais; a dominação, para obter bens simbólicos, realizar fantasias e experimentar a embriaguez do poder.

\section{Libertação}

A retirada dos assaltantes também é o momento em que tripulantes e passageiros precisam enfrentar as repercussões imediatas e mediatas da transação coercitiva. Mal os infratores saem de cena ${ }^{21}$ as vítimas entram em um momento de catarse emocional: choro, solidariedade, euforia e raiva se misturam. A raiva, por sinal, que estava represada, vem à tona sob a forma de reações compensatórias, de rompantes e bravatas para recuperar a face ou restaurar a autoestima masculina abalada pelo processo coercitivo:

Os passageiros depois do assalto ficam revoltados; muitos ficam falando que eles deveriam ter reagido, pois eram apenas dois [assaltantes], [sendo] que só um estava armado... é um sentimento de revolta, de incapacidade (motorista, 39 anos).

Muito além dos rompantes, o sentimento de revolta leva os assaltados a negarem o principio de autoridade contido na legalidade constitucional, no devido processo legal e no policiamento democrático, que deveria pautar a regulação dos delitos:

As pessoas... sentem frustração por ter perdido seus pertences, por que são agredidas; depois tem gente que defende bandido, por mim a polícia podia matar todo dia um bandido, não iria fazer nenhuma falta (motorista, 38 anos).

Nesse drama do crime à brasileira, a ilegalidade da ação de uns fornece a justificativa para a ilegalidade das reações de outros e, por conseguinte, para o enfraquecimento de qualquer autoridade regulatória.

Quanto ao motorista, ainda que partilhe os sentimentos de medo e alívio, ele reassume aos poucos seu papel de condutor e líder e passa a demonstrar domínio da situação. O primeiro desafio é deixar o local onde foram levados e confinados para o saque. Isso é mais fácil de resolver quando os ônibus não são danificados e podem retomar o rumo da estrada principal. Nesses casos, o rodoviário procura respeitar o prazo estabelecido pelos assaltantes antes de seguir viagem:

Eles tinham falado para ficar lá e só sair depois de 10 minutos. Quando deu o tempo, eu fui embora. Mandavam não olhar pra eles. Que estariam observando o carro e que se parássemos em algum lugar para falar com alguém eles iriam matar todos. Mas nos deixaram em paz, ainda bem (motorista, 45 anos).

As advertências verbais dos infratores para imobilizar as vítimas - ganhando tempo para fugir, retardar a comunicação do roubo (Luckenbill, 1981) e transportar os bens roubados identificáveis (Oliveira, 2007) até os pontos de entrega - exploram seu medo, projetando-o, de modo imaginário, no futuro imediato. É o modo de eles deixarem sua marca ou de buscarem estender seu controle sobre a cena depois de deixarem o local (Wright e Decker, 1997; Copes et al., 2012). Em certos casos, tais advertências, que jogam com a onipotência narcísica dos assaltantes, são acompanhadas por performances complementares: disparos para o ar e medidas de contenção física (Luckenbill, 1982), como jogar fora ou destruir a chave de ignição do veículo. ${ }^{22}$ Tripulantes e passageiros, incluindo pessoas idosas e crianças, são forçados, então, a caminhar, temendo outros ataques predatórios, vários quilômetros até a estrada principal para pedir ajuda a eventuais moradores ou motoristas em trânsito: 
Eles pegaram a chave quando eu desci. Um jogou no chão e atirou três vezes [na chave]. Depois de quase uma hora, não sei, eles pegaram tudo e avisaram para aguardar 10 minutos, no chão. Que tinha gente olhando. Quando deu o tempo certo eu levantei. Não tinha celular e nada. O jeito foi andar até a pista. Quase 15 minutos andando. Ficamos ali até aparecer alguém" (motorista, 35 anos).

$\mathrm{Na}$ sequência e antes de prosseguirem viagem até o local de destino, eles devem registrar queixa na delegacia mais próxima, o que pode significar, no caso de um estado extenso e subpovoado como a Bahia, uma longa distância, além de um tempo exaustivo, já que envolve muitas pessoas. $\mathrm{E}$, de fato, esses registros pouco ou nada contribuem para o esclarecimento dos fatos, o desmantelamento das redes dos assaltantes e mudanças no padrão de policiamento das estradas.

A viagem desastrosa nas "margens do Estado" vai se desdobrar em outras preocupações e providências. Urge ligar para parentes e empregadores, porém como fazê-lo se o celular também foi roubado? Evidentemente, os passageiros também não podem pagar despesas com alimentação e passam a depender da boa vontade de terceiros. Para os rodoviários é difícil evitar, pelas regras vigentes nas empresas de transporte, o retorno mais ou menos imediato ao trabalho no mesmo itinerário e horário onde aconteceu o assalto, o que pode acentuar o pânico a uma experiência análoga. Além de ter que lidar com o trauma vivido, as vítimas vão precisar repor os bens roubados sem nenhuma indenização por parte das empresas. Mas, afinal de contas e como acrescentou um entrevistado: "As pessoas perderam as coisas, mas não foi perda total, entende? Porque vida é perda total. Se você perde a vida, não recupera mais" (motorista, 32 anos).

\section{Reflexóes finais}

Neste trabalho sobre vitimização e percepção de medo, analisamos os padrões de transação e confronto (Luckenbill, 1981; Best e Luckenbill, 1982) entre tripulantes e passageiros de ônibus interurbanos e os chamados assaltantes de estrada. Conquanto o foco sejam as interpretações, as reações e as respostas das vítimas, buscamos levar em conta a manipulação do medo (Jacobs, 2012, 2013), a gestão de cenas e circunstâncias (Copes et al., 2012) e as habilidades gestoras (Gill, 2000, 2001) acionadas pelos perpetradores desse crime de contato direto, violento e inédito para os padrões da "antiga" sociologia do desvio e da mais recente criminologia da vida cotidiana (Garland, 2002). No estado da Bahia, em um ano apenas, 2013, foram registradas 524 ocorrências, atingindo pelo menos 17.816 passageiros.

Apesar da falta do ponto de vista dos autores do crime, esta investigação fez achados acerca da influência dos alvos e do estilo de gestão coercitiva nas variaçôes do uso da violência psicológica e física para manipular o medo e lograr a aceitação das vítimas nas distintas fases dessa troca social predatória. Efetivamente, as características do ônibus, tais como a velocidade, transitoriedade e possibilidade de ser utilizado como arma e escudo (Jacobs, 2013), constituem um desafio e uma oportunidade para os assaltantes. À medida que amplia a gama de ações de captura, a velocidade requer esquemas estratégicos específicos (Copes et al., 2012) para o estabelecimento da copresença: a infiltração dos assaltantes entre os passageiros, os bloqueios das vias e os ataques aos veículos. Embora não tenhamos esclarecido os critérios de preferência dos infratores por tais esquemas, estes são, seguramente, mais diversificados, ousados e perigosos do que os apontados pela literatura (Gill, 2001; Jacobs, 2012, 2013; Copes et al., 2012). Ao mesmo tempo que alguns ataques precipitam desfechos desastrosos para os veículos e seus ocupantes, outros antecipam claramente o compartilhamento da definição de situação de roubo com o motorista.

A multiplicidade - quantidade e diversidade de vítimas nesses encontros, por sua vez, contrasta com o enquadramento de um ou poucos indivíduos isolados que acontece nos roubos ordinários (Luckenbill, 1981; Best e Luckenbill, 1982; Gill, 2001; Jacobs, 2012, 2013; Copes et al., 2012). O fato de o roubo a onibus atingir de modo sucessivo e diferenciado uma média de trinta vítimas de cada vez tem implicaçóes significativas sobre o gradiente de violência psicológica e física empregado para a manipulação do medo. 
De um lado, este gradiente de violência envolve performances (Turner, 1987; Alexander, 2004) que exibem, potencializam e contribuem para a materialização de ações que sensibilizam as vítimas. Diferentes das ações violentas discretas contra alvos discretos que estão presentes na totalidade dos roubos, tais performances são expansivas, contagiantes ou capazes de propagarem o medo entre audiências mais amplas. Entre essas exibições destacam-se os ataques cinematográficos, acompanhados por perseguição e tiros, para a captura do ônibus. Há também o arsenal de gestos, xingamentos e ameaças, seguido pelo anúncio do assalto e invasão do ônibus, que leva tripulantes e passageiros a reagirem com espanto, gritaria e pânico, para depois entrarem em uma fase de aceitação (Alexander, 2004). Em terceiro lugar, tem as performances de inversão dos papéis de autoridade entre rodoviários e infratores (Paes-Machado e Levenstein, 2004) e, eventualmente, entre estes últimos e policiais presentes. Em quarto, está a desenvoltura dos infratores, com advertências, revistas e buscas abusivas para esquadrinhar e vasculhar possíveis lugares onde os bens estão guardados ou podem ter sido escondidos, despojando e aniquilando as resistências das vítimas. Por fim, há as advertências que jogam com a onipotência dos assaltantes e medidas de contenção física para imobilizar os assaltados e estender o controle após eles terem abandonado a cena.

De outro lado, existem variações no tipo e no nível de violência que remetem aos papéis diferenciados e às reações dos tripulantes e passageiros nas diversas etapas da transação coercitiva. Nesse sentido, a vitimização psicológica dos motoristas é maior nas fases do estabelecimento da copresença (the onset) via captura do veículo e do compartilhamento da definiçãao de situação de roubo do que nas etapas posteriores da transação, quando os passageiros substituem aqueles como os alvos principais das ameaças. A receita cruel dessa vitimização envolve a intermitência das ameaças e reforço para promover a sensação de medo (Jacobs, 2013) e dificultar a retomada de agência das vítimas. Afora isso, supomos que a produção desses estímulos opera como um chamamento para os próprios assaltantes, para ficarem de prontidão diante dos desafios cambiantes das cenas e das circunstâncias. Um achado importante diz respeito às diferenças entre assaltantes amadores e pro- fissionais no que tange às habilidades gestoras (Gill, 2000, 2001). Apesar de as espirais de violência ligadas aos roubos e a outros crimes predatórios contribuírem para diluir as diferenças entre essas categorias polares, afirmamos que os profissionais continuam se distinguindo por sua competência para manipular o medo e alargar a margem de colaboração das vítimas. De qualquer modo, em contraste com o estilo de gestão nervoso e truculento dos inexperientes, os profissionais dosam a manipulação do medo e alargam a margem de colaboração dos assaltados. De qualquer modo, a vitimização psicológica provocada por uns e outros atinge tais extremos em algumas cenas, como as da invasão e desvio do veículo e das buscas, que geram pânico entre os alvos.

A vitimização física apresenta um padrão semelhante. No que se refere aos motoristas, ela é mais elevada na fase crítica do estabelecimento da copresença; no caso dos passageiros, ela é maior na progressão do roubo (Lindegaard et al., 2015), em especial na etapa da apropriação dos bens. As evidências sugerem que este pico de vitimização resulta também do estilo de gestão amadorístico dos assaltantes e, por conseguinte, do modo como estes respondem aos desafios representados pela resistência material, a demora para entregar os pertences e as crises emocionais dos assaltados. Ao mesmo tempo que fomenta emoções contraproducentes, o amadorismo faz os assaltantes incrementarem, ao modo de um efeito pingue-pongue, o uso da violência física para obter o que desejam, reestabelecer a autoridade ou manter sua reputação (Jacobs, 2013). Além dessa noção de resistência material, a pesquisa verificou a existência de uma modalidade coletiva de resistência verbal forçosa (forceful) (Block e Skogan, 1986) - favorecida pela superioridade numérica dos passageiros e pela duração mais longa dessa modalidade de roubo - para interromper ou reduzir a violência crescente contra algumas vítimas, que não havia sido analisada até aqui pela literatura especializada.

Por fim, os processos de estruturação da vitimização - a exemplo da oferta de oportunidades ilícitas (Cloward e Ohlin, 1960), das vantagens ecológicas (St. Jean, 2007), das dificuldades de policiamento das estradas e da desregulação da se- 
gurança- evidenciam a complexidade de controle desse tipo de ação. Vale, a esse respeito, um breve comentário acerca do avanço da privatização do policiamento das viagens de ônibus. Tal privatização expressa-se na contratação de serviços de escoltas armadas motorizadas - muitas delas integradas por policiais fora de serviço - para acompanhar comboios de ônibus em viagens noturnas. Apesar dos custos financeiros e da dificuldade de operacionalização - por conta da grande quantidade, variedade e quase sobreposição de viagens -, a contratação desse serviço tornou-se obrigatória para muitas empresas e um atrativo poderoso para os passageiros. Assim, mesmo quando as empresas suspendem temporariamente as escoltas- em certos itinerários, trechos e dias da semana específicos -, elas acabam retomando-as depois de novos ataques. Quanto às empresas que não podem pagar ou implementar tal prática de segurança, elas se restringem a viagens diurnas para evitar assaltos. Tamanha dependência do serviço privado é mais uma confirmação da desregulação da segurança do transporte de ônibus interurbanos ou das próprias condições de possibilidade desses roubos.

\section{Notas}

1 Disponível em http://www.24-horas.mx/las-rutas-del-hampa/, consultado em 4/3/2014, ehttp://peru21.pe/ noticia/596272/no-hay-seguridad-carreteras, acessado em 4/3/2014.

2 Os ataques aconteciam com tamanha frequência nos anos de 1980, nas linhas que passavam pela rodovia Presidente Dutra, a principal ligação entre Rio de Janeiro e São Paulo, e na linha Rio de Janeiro-Petrópolis, que tais linhas foram denominadas "roleta russa" (Folha de S. Paulo, 18/6/1989).

3 Em 1984, em menos de seis meses, vinte pessoas foram feridas ou mortas em cinquenta assaltos (Folha de S. Paulo, 27/5/1984).

4 No Rio de Janeiro foi noticiado pela primeira vez um caso de desvio do veículo de sua rota e uso de carros de apoio para carregar os bens roubados dos passageiros. $\mathrm{Na}$ mesma ação, a triagem das vítimas foi observada na advertência feita pela quadrilha de que "se ali houvesse policial ele não escaparia" (Folha de S. Paulo, 18/5/1982).
5 Desde então, os ônibus com destinos comerciais (Foz de Iguaçu, bairro do Brás em São Paulo e a feira de Tobias Barreto, em Sergipe) ou que transportam passageiros abonados, a exemplo de garimpeiros na região Norte e turistas no Nordeste (Folha de S. Paulo, $11 / 8 / 1983 ; 7 / 2 / 2001)$, são alvos preferenciais das quadrilhas (Folha de S. Paulo, 9/6/2005).

6 Também em meados da década de 80 constatou-se que medidas de segurança, como a formação de comboios e uso de detectores de metais no Terminal do Tietê, não logravam impedir os assaltos (Folha de S. Paulo, 27/5/1984).

7 O estado da Bahia possui 53 empresas concessionárias e permissionárias que exploram 1.357 linhas de transporte e empregam 18 mil rodoviários interestaduais e intermunicipais. Tais empresas transportaram, em 2007, 1.454 .003 passageiros em 57.202 viagens intermunicipais e interestaduais (Agerba, 2014).

8 O número de roubos nesse período foi: 425, em 2008; 604, em 2009; 463, em 2010; 464, em 2011; 480, em 2012; 524, em 2013 (SSP, 2014).

9 A média calculada segue as recomendaçôes do centro de operações da Agerba (Agência Estadual de Regulação de Serviços Públicos de Energia, Transporte e Comunições da Bahia), em contato pessoal em maio de 2014.

10 Os veículos são classificados em comerciais e executivos. Os primeiros, conhecidos como pinga-pinga pelas constantes paradas para embarque e desembarque, são menos confortáveis e mais baratos que os ônibus executivos. Estes últimos, por sua vez, raramente param fora das estaçóes rodoviárias e dos pontos de apoio das empresas e oferecem viagens em horários noturnos. Enquanto os veículos comerciais estão mais expostos à infiltração por falsos passageiros, os executivos tendem a ser capturados por meio do bloqueio das vias e de ataques rápidos.

11 Falsas operações policiais ocorreram na Bahia na primeira onda registrada de crimes (Folha de S. Paulo, 20/5/2004). No estado do Paraná, por sua vez, em 2003, seis homens vestidos de policiais militares e com um veículo com distintivo roubaram $\mathrm{R} \$ 30$ mil de um grupo de sacoleiros que viajava na linha Mogi das Cruzes-Foz de Iguaçu (Folha de S. Paulo, 21/10/2003).

12 Em 2003, um motorista que tentou furar um bloqueio, feito com duas carretas, no sudoeste do Paraná foi baleado por assaltantes (Francisco, 2003).

13 Ainda segundo este mesmo entrevistado: "A reação da gente é de nervosismo, medo. A gente vê, sente muito a inexperiência deles [dos amadores], aquele nervo- 
sismo, fica só imaginando os gestos deles... podem atirar" (motorista, 45anos).

14 Para os rodoviários, o passageiro/assaltante só entra no veículo quando ultrapassa a barreira entre a cabine do motorista e a ala dos passageiros.

15 Considerando o medo de disparos efetuados por policiais e vigilantes, sua imobilização é recebida com certo alívio pelos rodoviários.

16 Foi no final de um destes encontros e já saindo do ônibus que um assaltante, acrescentando uma nota justificatória (Cohen, 2005) e irônica na performance crua e tensa do roubo, declarou: "Tchau pessoal, desculpem, tudo isso é culpa do sistema" (lojista, 52 anos).

17 "Apesar da cooperação, a cobiça pode gerar disputas entre os próprios assaltantes e precisam ser controladas para não colocar em risco o sucesso da ação. Em 2007, embora dois assaltantes estivessem envolvidos em uma ação de grande envergadura - o roubo a três onibus que viajavam em comboio -, eles travaram uma discussão sobre a posse de um par de tênis e de calças em uso por um passageiro, que cessou somente após a intervenção de um terceiro assaltante" (Inoue-Viodres e Paes-Machado, 2010, p. 18).

18 Os passageiros também podem tentar persuadir os assaltantes a não tomarem objetos considerados de estimação.

19 Na sua rapacidade, os agentes do crime ficam frustrados quando o rendimento fica abaixo do esperado, como em um assalto em que um deles que atirou as bolsas de volta contra os passageiros e ironizou: "Outro dia, nós assaltamos um ônibus comercial e rendeu muito mais. Vocês são uns m... Viajam de ônibus de luxo para fazer farol e não têm dinheiro nenhum" (Mayrink, 1984).

20 A demora dos passageiros para entregarem seus bens também foi castigada em mais dois episódios: "teve uma senhora de idade que eles bateram na cara da coitada porque ela demorou para dar os pertences. Acho que ela ficou nervosa na hora e demorou para entregar" (motorista, 38 anos).Em outro assalto, um rapaz foi golpeado na cabeça para apressar a abertura da sua valise: "Estava muito nervoso e não conseguia compreender direito o que eles queriam. Ele tinha uma valise que estava trancada e não conseguiu abrir. Isso estressou eles, e eu fiquei com medo de fazerem algo pior com ele" (assistente social, 43 anos).

21 Após abrirem ou mandarem o motorista abrir o bagageiro, fazem uma rápida triagem para escolher o que será levado e carregam os bens em carros e utilitários, no lombo de animais ou até mesmo a pé. Em contrapartida, nos roubos a ônibus urbanos os assaltantes usam esses transportes para se aproximarem das rotas de fuga (Paes-Machado e Levenstein, 2004).

22 Eles também podem amarrar, amordaçar e prender as vítimas nos bagageiros do ônibus (Folha de S. Paulo, 13/2/1984, 23/3/1984, 7/1/1987, 18/8/2006).

\section{BIBLIOGRAFIA}

ÁGEL, Arturo. (2013), "Las rutas del Hampa". 24 Horas - El Diario sin Limites, fev. Disponível em http://www.24-horas.mx/las-rutas-del-hampa/, consultado em 4 mar. 2014.

AGERBA - Agência Estadual de Regulação de Serviços Públicos de Energia, Transporte e Comunicaçōes da Bahia. (2014), "Informaçōes sobre transporte de passageiros". Disponível em www.agerba.gov.ba, consultado em dez. 2014.

AQUINO, J. P. D. \& SÁ, L. D. de. (2014), "Consideração e competência entre assaltantes: etnografias da socialidade armada", in C. Barreira, J. P. D. Aquino e L. D. de Sá, Violência, ilegalismos e lugares morais. Campinas, Pontes.

ALEXANDER, J. C. (2004), "Cultural pragmatics: social performance between rite and strategy". Sociological Theory, 22 (4): 527-573.

ANTT - Agência Nacional de Transporte Terrestre. (2007), "Relatório anual". Disponível em www.antt.gov.br, consultado em dez. 2009.

ABRATI - Associação Brasileira Empresas de Transporte Terrestre de Passageiros. (2008), "Relatório nacional anual de 2007". Disponível em www.antt.gov.br, consultado em 6 nov. 2009.

BEST, J. \& LUCKENBILL, D. F. (1982). Organizing deviance. New Jersey, Prentice-Hall.

BLUMSTEIN, A. \& WALLMAN, J. (eds.). (2006), The crime drop in America. Nova York, Cambridge University Press.

BLOCK, R. \& SKOGAN, W. G. (1986), "Resistance and nonfatal outcomes in stranger-to-stranger predatory crime". Violence and Victi$m s, 1$ (4): 241-253.

CALDEIRA, T. P. do R. (2000), A cidade de muros: crime, segregação e cidadania em São Paulo. São Paulo, Editora 34/Edusp. 
CLOWARD, R. A. \& OHLIN, L. E. (1960), Delinquency and opportunity. Nova York, Free Press.

CNT - Confederação Nacional de Transportes. (2007), "Pesquisa Rodoviária”. Disponível em www.cnt.org.br, consultado em 6 nov. 2009.

COHEN, L. E. \& FELSON, M. (1979), "Social change and crime trends: a routine activities approach". American Sociological Review, 44: 88-100.

COHEN, S. (2005), Estados de negación: ensayos sobre atrocidades y sufrimiento. Buenos Aires, Universidad de Buenos Aires.

COPES, H.; HOCHSTETLER, A \& CHERBONNEAU, M. (2012), "Getting the upper hand: scripts for managing victim resistance in carjackings". Journal of Research in Crime and Delinquence, 49 (2): 249-268.

CORNISH, D. \& CLARK, R. (1985), “Modeling offenders decisions': a framework for research and policy", in M. Tonry e N. Morris, Crime and justice, Chicago, University of Chicago Press.

COSTA, L. et al. (2003), "Morbidade declarada e condições de trabalho: o caso dos motoristas de São Paulo e Belo Horizonte". São Paulo em Perspectiva, 17 (2): 54-67.

DEAKIN, J.; SMITHSON, H.; SPENCER, J. \& MEDINA-ARIZA, J. (2007), "Taxing on the streets: understanding the methods and process of street robbery". Crime Prevention and Community, 9: 52-67.

EINSTADTER, W. J. (1966), Armed robbery: a career study in perspective. Berkeley, $\mathrm{PhD}$ Thesis, University of California.

FABIÃO, C.; BARBOSA, A.; FLEMING, M. \& SILVA, C. (2008), "Rastreio da perturbação de somatização nos cuidados primários de saúde: um estudo piloto". Acta Med. Port., 21 (4): 319-328.

FELSON, M. (2006), Crime and nature. Thousand Oaks/Londres/New Delhi, Sage.

FOLHA DE S. PAULO. (1971), "Ônibus assaltado". Folha de S. Paulo, 4 fev.

. (1982), "Oito bandidos saqueiam ônibus em Duque de Caxias. Folha de S. Paulo, 18 maio.
(1983), "Ônibus assaltado na Transamazônica”. 11 ago.

. (1984), "O saque ao ônibus de turismo". Folha de S. Paulo, 13 fev.

(1984), "Apurado roubo contra turistas". Folha de S. Paulo, 23 mar.

. (1984), "Ônibus continuam alvos fáceis de ladrōes na estrada". Folha de S. Paulo, 27 maio.

. (1985), "Ladrões trocam tiros em ônibus na Dutra e um morre". Folha de S. Paulo, 24 maio.

(1985), "Bandidos em Manhuaçu sequestram ônibus e saqueiam passageiros". Folha de S. Paulo, 29 jul.

(1987), "Turistas argentinos assaltados no Rio Grande do Sul". Folha de S. Paulo, 7 jan.

(1988), "Assaltante mata passageiro que dormia no ônibus". Folha de S. Paulo, 14 dez.

. (1989), "Rio-Petrópolis: roleta russa nos ônibus". Folha de S. Paulo, 18 jun.

. (2001), "Ônibus com 57 turistas estrangeiros é assaltado por quadrilha na Bahia". Folha de S. Paulo, 7 fev.

(2001), "Ônibus tomba após cerco e é assaltado". Folha de S. Paulo, 2 ago.

. (2002), "Quatro assaltantes são mortos a tiros". Folha de S. Paulo, 23 nov.

(2003), "Falsos PMs assaltam ônibus de sacoleiros". Folha de S. Paulo, 21 out.

(2004), "Violência faz ônibus sair em comboio na BA: medida foi tomada após 99 assaltos registrados em 2004". Folha de S. Paulo, 20 maio.

(2005), "Desvio de rota, assalto e muito medo no ônibus". Folha de S. Paulo, 9 jun.

. (2006), "Sacoleiros ficam presos no bagageiro". Folha de S. Paulo, 18 ago.

. (2007), "Ônibus cai em ribanceira durante assalto em MG”. Folha de S. Paulo, 24 nov.

(2008), "Ladrões deixam sacoleiros nus após roubo". Folha de S. Paulo, 11 nov.

FRANCISCO, L. (2003), "Quadrilha fecha rodovia e assalta quatro ônibus". Folha de S. Paulo, 20 mar. 
GARLAND, D. (2002), The culture of control-crime and social order in contemporary society. Oxford, Oxford University Press.

GILL, M. (2001), "The craft of robbers of cash-in-transit vans: crime facilitators and the entrepreneurial approach". International Journal of the Sociology of Law, 29 (3): 277-291.

GOFFMAN, E. (1975), A representação do eu na vida cotidiana. Petrópolis, Vozes.

HALLSWORTH, S. (2005). Street crime. Cullompton, Devon, Willan.

HOBBS, D. (1988), Doing the business: entrepreneurship, dectectives and the working class in the East End of London. Oxford/Nova York, Oxford University Press.

HOLLANDER, E. \& SIMEON, D. (2006), "Transtornos de ansiedade, in R. Hales e S. C. Yudofsky, Tratado de psiquiatria clínica, Porto Alegre, Artmed.

HUGGINS, M. K. et al. (2006), Operários da violência: policiais torturadores e assassinos reconstroem as atrocidades brasileiras. Brasília, Editora da UnB.

JACOBS, B. A. (2012), "Carjacking and copresence". Journal of Research in Crime and Delinquency, 49 (4): 471-488.

. (2013), "The manipulation of fear in carjacking". Journal of Contemporary Ethnography, 45 (5): 523-544.

KATZ, J. (1991). Seductions of crime: moral and sensual aspects of doing evil. Nova York, Basic Books.

LETKEMANN, P. (1973), Crime as work. Englewood Cliffs/New Jersey, Prentice-Hall.

LINDERGAARDEN, M. R.; BERNASCO, W. \& JACQUES, S. (2015), "Consequences of expected and observed victim resistance for offender violence during robbery events". Journal of Research in Crime and Delinquency, 52 (1): 32-61.

LINGER, D. (1992), Dangerous encounters. Stanford, Stanford University Press.

LUCKENBILL, D. (1981), "Generating compliance: the case of robbery". Journal of Contemporary Ethnography, 10: 25-46.

MATTHEWS, R. (2002), Armed robbery. Devon/ Portland, Willan Publishing.

MCCLUSKEY, J. D. (2013), "A comparison of ro- bbers' use of physical coercion in commercial and street robberies". Crime \& Delinquency, 59 (3): 419-442.

MAYRINK, J. M.(1984), "Assalto ao ônibus e três horas de tiro e terror". Folha de S. Paulo, 16 dez.

MISSE, M. (2008), "Sobre a acumulação social da violência no Rio de Janeiro”. Civitas, 8 (3): 371-385.

NORMANDEAU, A. (1968), Trends and patterns in crimes of robbery. Unpublished dissertation, University of Pennsylvania, Philadelphia.

OLIVEIRA, I. M. S. (2007), Do vapor ao sapatinho: organização das quadrilhas e gerenciamento de vitimas de roubos a banco. Salvador, dissertação de mestrado, Instituto de Saúde Coletiva, Universidade Federal da Bahia.

PAES-MACHADO, E. \& LEVENSTEIN, C. (2004), "I'm sorry everybody, but this is Brazil: armed robbery on the buses in Brazilian cities". Brit. J. Criminol., 44: 1-14.

\& NASCIMENTO, A. M. (2011), "Bank employees don't go to heaven: processes of victimization of bank employees for violent crimes", in A. N. Hutcherson (ed.), Psychology of victimization, Nova York, Nova Science Publishers. \& NASCIMENTO, A. M. (2014), "Conducting danger: governance, networks, and layperson security intelligence among taxi drivers". International Journal of Comparative and Applied Criminal Justice, 38 (1): 1-22.

\& RICCIO-OLIVEIRA, M. A. (2009),

"O jogo de esconde-esconde: trabalho perigoso e ação social defensiva entre motoboys de Salvador". RBCS, 24 (70): 91-106.

PERÚ 21. (2010), "No hay seguridad en carreteras del Perú". Péru 21, 14 jul. Disponível em http://peru21.pe/noticia/596272/no-hay-seguridad-carreteras, consultado em 4 mar. 2014.

POLÍCIA RODOVIÁRIA FEDERAL. "BR-116: Assaltos migram para trecho sem luz". Disponível em http://sinprfrj.org.br/pt-br/content/ br-116-assaltos-migram-para-trecho-sem-luz, consultado em 18 set. 2010.

REIS, T. (2014), "GO e DF concentram mais da metade dos assaltos a ônibus em rodovias". Portal de Notícias da Globo G1 Brasil. Dis- 
ponível em http://m.g1.globo.com/brasil/ noticia/2014/02/go-e-df-concentram-mais-da-metade-dos-assaltos-onibus-em-rodovias. html?menu=5c719a78bd00b16, consultado em $1^{\circ}$ mar. 2014.

ROITMAN, J. (2004), "Productivity in the margins: the reconstitution of state power in the chad basin". in V. Das e D. Poole, Anthropology in the margins of the State. Santa Fé, School of American Research Press.

SSP-BA - Secretaria de Segurança Pública do Estado da Bahia (2007), "Registros de roubos a ônibus". Salvador, SSP-BA. . (2014), "Registros de roubo a ônibus". Salvador, SSP-BA.

ST. JEAN, P. (2007), Pockets of crime: broken windows, collective efficacy and the criminal point of view. Chicago/Londres, University of Chicago Press.

SYKES, G. M. \& MATZA, D. (2008), “Técnicas de neutralización: una teoria de la delincuencia”. Caderno CRH, 21 (52): 163-170.

TARK, J. \& KLECK, G. (2004), "Resisting crime: the effects of victim action on the outcomes of crime". Criminology, 20 (2), 89-116.

TEDESCHI, J. \& FELSON, R. B. (1994), Violence, aggression, and coercive actions. Washington, DC, American Psychological Association.

TELLES, V. da S. (2010), A cidade nas fronteiras do legal e ilegal. Belo Horizonte, Argumentum.

TURNER, V. (1987), "The anthropology of performance", in Victor Turner, The anthropology of performance, Nova York, PAJ Publications.

VEBLEN, T. (1924), The theory of the leisure class. Londres, Allen \& Unwin.

VIODRES-INOUE, S. R. \& PAES-MACHADO, E. (2010), "A organização social do roubo com confinamento forçado: o caso dos ônibus interurbanos executivos em rodovias". Anais do $34^{\circ}$ Encontro Anual da Anpocs, pp. 1-25.

VOLKOV, V. (2002), Violent entrepreneurs: the use of force in the making of Russian capitalism. Ithaca/Londres, Cornell University Press.

WRIGHT, R. T. \& DECKER, S. H. (1997), Armed robbers in action. Boston, Northeastem University Press.
ZALUAR, A. (1994), "A moeda e a lei", in , Condominio do diabo, Rio de Janeiro, Revan/Editora da UFRJ.

ZIMRING, F. E. (2007), The great American crime decline. Nova York, Oxford University Press. 


\section{O LADO SOMBRIO DA ESTRADA: VITIMIZAÇĀO, GESTÃO COERCITIVA E PERCEPÇÃO DE MEDO NOS ROUBOS A ÔNIBUS INTERURBANOS}

\author{
Eduardo Paes-Machado e Silvia \\ Viodres-Inoue
}

Palavras-chave: Transporte de passageiros; Vitimização; Transação coercitiva; Percepção de medo.

Este trabalho discute a vitimização e a percepção do medo nos roubos a ônibus interurbanos no estado da Bahia, Brasil. Analisa entrevistas com rodoviários e passageiros, e matérias jornalísticas. Compara a vitimização nos roubos efetuados na estrada com a dos roubos em que os ônibus são desviados do seu percurso. Argumenta que o emprego da violência psicológica e física para manipular a percepção do medo é influenciado pelas características dos veículos, pela multiplicidade de vítimas e pela duração prolongada da interação. Relaciona as variações no tipo e nível de vitimização com o estilo de gestão dos assaltantes, os papéis diferenciados e as respostas dos tripulantes e passageiros nas fases da transação coercitiva. Conclui defendendo a urgência da regulação de tais crimes e da segurança do transporte de ônibus interurbanos.

\section{THE DARK SIDE OF THE HIGHWAY: VICTIMIZATION, COERCITIVE MANAGEMENT AND THE PERCEPTION OF FEAR IN INTERCITY BUS ROBBERIES}

\author{
Eduardo Paes-Machado and Silvia \\ Viodres-Inoue
}

Keywords: Passenger transportation; Intercity bus robberies; Victimization; Coercitive transaction; Fear perception.

The paper discusses the issue of victimization and the perception of fear in interurban bus robberies in the state of Bahia, Brazil. Analyzing interviews with bus drivers and passengers as well as news reports, it compares the victimization taking place during bus robberies on the highways themselves and during the robberies affecting buses diverted off their routes. It argues that the use of psychological and physical violence in order to manipulate the perception of fear is influenced by the characteristics of the vehicles, the multiplicity of victims, and the length of time involved in the interaction. In this sense, it relates the variations on the type and level of victimization to the management style used by the muggers, their different roles, and the crews' and passengers' reactions in the various phases of the coercive transaction. The paper concludes by arguing that it is urgent for the state to exercise its regulatory authority over such field of criminality and to improve security in transportation through interurban buses.

\section{LA FACE CACHÉE LA ROUTE: VICTIMISATION, GESTION COERCITIVE ET PERCEPTION DE LA PEUR EN LIEN AVEC LES VOLS COMMIS DANS LES AUTOBUS DES RÉSEAUX INTERURBAINS}

\author{
Eduardo Paes-Machado et Silvia \\ Viodres-Inoue
}

Mots-clés: Transport de passagers; Victimisation; Transaction coercitive; Peception de la peur.

Ce travail porte sur la victimisation et la perception de la peur dans les vols commis dans les autobus des réseaux interurbains de l'état brésilien de Bahia. Il analyse des entretiens d'employés des transports et de passagers, ainsi que des articles de journaux. D'autre part, il compare la victimisation des vols commis pendant le trajet des vols de celle des vols où les autobus sont déviés de leur parcours par les agresseurs. Il observe que l'emploi de la violence psychologique et physique pour manipuler la perception de la peur est influencé par les caractéristiques des véhicules, par la multiplicité de victimes et par la durée prolongée de l'interaction. Un lien est établi entre les variations du type et du niveau de victimisation et le style de gestion des braqueurs, les rôles différenciés et les réponses des employés et des passagers pendant la transaction coercitive. Finalement, le travail défend l'urgence de la régulation de tels crimes et de la sécurité du transport dans les bus interurbains. 